\title{
DETERMINISME TEKNOLOGI KOMUNIKASI DAN GLOBALISASI MEDIA TERHADAP SENI BUDAYA INDONESIA
}

\author{
Sigit Surahman \\ Dosen Program Studi Ilmu Komunikasi FISIP Universitas Serang Raya \\ Jalan Raya Serang-Cilegon Km. 5, (Taman Drangong) Serang-Banten \\ No.HP.: 087771297819 E-mail: saleseven@gmail.com
}

\begin{abstract}
Abstrak
Penelitian ini berfokus pada pengaruh terpaan teknologi komunikasi dan globalisasi media terhadap seni budaya Indonesia. Determinasi teknologi komunikasi atau terpaan teknologi komunikasi hadir di tengah-tengah masyarakat dan memengaruhi cara pandang dan perilaku manusia dalam kehidupan sehari-hari. Teknologi komunikasi dan media merupakan dwitunggal yang tidak dapat dipisahkan karena keduanya hadir saling melengkapi. Perkembangan media ini semakin pesat dan canggih seiring dengan perkembangan teknologi komunikasi saat ini. Terpaan teknologi dan media ini memengaruhi seni budaya dan perilaku masyarakat atau bangsa Indonesia. Analisis deskriptif kualitatif merupakan metode pengkajian yang digunakan dengan tujuan mengungkap fakta, keadaan, fenomena, variabel, dan keadaan yang terjadi saat penelitian berjalan dan menyuguhkan apa adanya. Variabel dalam penelitian ini adalah teknologi komunikasi, globalisasi media, dan seni budaya Indonesia. Dengan menggunakan analisis deskriptif kualitatif pengkajian ini akan mengungkap pengaruh terpaan teknologi dan globalisasi media terhadap seni budaya Indonesia.
\end{abstract}

Kata Kunci: determinisme, globalisasi, media, seni, budaya

\begin{abstract}
The Determinism of Communication Technology and Media Globalization Towards Arts and Indonesian Culture. This study focuses on the effect of the exposure of media communications technology and the globalization of the art and culture in Indonesia. Determination of communications technology or the exposure of communications technology present in the midst of society and influence the worldview and human behavior in everyday life. Communication technology and media are a duumvire that cannot be separated, both present complementary. The increasingly rapid development of media and its advancement are along with the development of communication technology. The exposure of media and technology affects art and culture as well as the behavior of people or the Indonesian. Qualitative descriptive analysis is the method of assessment used to uncover the facts, phenomena, variables and circumstances that occurred while running the research and presenting it as what it is. The variables in this study are technology, media globalization, and Indonesian arts and culture. By using qualitative descriptive analysis, this study will reveal the influence of technology and media globalization exposure to the art and culture of Indonesia .
\end{abstract}

Keywords: determinism, globalization, media, art, culture

\section{PENDAHULUAN}

Perkembangan teknologi komunikasi menjadikan interaksi antarmanusia dan budaya menjadi lebih cepat, efektif, dan efisien. Keberadaan teknologi komunikasi telah menjadi bagian yang tidak terpisahkan dari kehidupan manusia modern seperti saat ini. Bahkan dapat dikatakan, hampir seluruh aspek kehidupan manusia seperti bidang pendidikan, sosial, politik, dan ekonomi, bahkan seni dan budaya 
telah bersentuhan dengan teknologi. Kehadiran teknologi komunikasi juga tidak bisa dilepaskan dengan globalisasi media karena keberadaan teknologi komunikasi memudahkan manusia dari seluruh penjuru dunia bisa berkomunikasi secara langsung dan massal. Bukan hanya itu, berbagai kebudayaan juga bisa berbaur pada saat yang bersamaan tanpa mengenal batas ruang dan waktu.

Teknologi komunikasi dan globalisasi pada hakikatnya ternyata telah membawa nuansa budaya dan nilai yang memengaruhi selera dan gaya hidup masyarakat. Melalui media yang kian terbuka dan terjangkau, masyarakat menerima berbagai informasi tentang peradaban baru yang datang dari seluruh penjuru dunia. Masyarakat menyadari belum semua warga negara mampu menilai sampai di mana masyarakat sebagai bangsa yang beradab. Misalnya, banjir informasi dan budaya baru yang dibawa media baik media cetak maupun media elektronik tidak jarang teramat asing dari sikap hidup dan norma yang berlaku di Indonesia.

Perkembangan teknologi dan globalisasi merupakan sebuah fenomena khusus dalam peradaban manusia yang bergerak terusmenerus dalam masyarakat global dan merupakan bagian dari proses manusia global itu sendiri. Kehadiran teknologi informasi dan teknologi komunikasi mempercepat akselerasi proses globalisasi ini. Globalisasi menciptakan berbagai tantangan dan permasalahan baru yang harus dijawab dan dipecahkan dalam upaya memanfaatkan globalisasi untuk kepentingan kehidupan.

Tidak dapat dipungkiri lagi bahwa teknologi komunikasi dan globalisasi kini menjadi satu kesatuan yang santer terdengar di seluruh dunia sejak awal abad 21. Pro- kontra pun selalu mewarnai perjalanannya sebagai sebuah fenomena. Perubahan yang terjadi secara menyeluruh, dirasakan secara kolektif, dan memengaruhi banyak orang (lintas wilayah, lintas negara, lintas budaya) yang memengaruhi gaya hidup dan lingkungan. Dunia memang selalu berubah dan globalisasi adalah dunia yang terhubung (connected world) seolah tanpa ada batasnya; atau meminjam istilahnya McLuhan sebagai global village (Fakih, 2006:87; McLuhan, 1994:12).

Globalisasi memiliki banyak penafsiran dari berbagai sudut pandang. Sebagian orang menafsirkan globalisasi sebagai proses pengecilan dunia atau menjadikan dunia sebagaimana layaknya sebuah perkampungan kecil. Sebagian lainnya menyebutkan bahwa globalisasi adalah upaya penyatuan masyarakat dunia dari sisi gaya hidup, orientasi, dan budaya. Pengertian lain dari globalisasi seperti yang dikatakan oleh Barker (2004:76) adalah bahwa globalisasi merupakan koneksi global ekonomi, sosial, budaya, dan politik yang semakin mengarah ke berbagai arah di seluruh penjuru dunia dan merasuk ke dalam kesadaran manusia.

Konsep akan globalisasi menurut Robertson dalam Bungin (1992:25), mengacu pada penyempitan dunia secara insentif dan peningkatan kesadaran manusia akan dunia, yaitu semakin meningkatnya koneksi global dan pemahaman manusia akan koneksi tersebut. Penyempitan dunia dapat dipahami dalam konteks institusi modernitas dan intensifikasi kesadaran dunia dapat dipersepsikan refleksif dengan lebih baik secara budaya.

Teknologi komunikasi dan globalisasi dalam perkembangannya menimbulkan berbagai masalah dalam bidang kebudayaan, misalnya mulai menipis dan hilangnya budaya- 
budaya asli suatu negara atau suatu daerah, terjadinya erosi nilai-nilai budaya, menurunnya rasa kepercaayaan diri akan budaya bangsa sendiri, dan menipisnya gaya hidup ketimuran atau meningkatnya gaya hidup kebarat-baratan.

\section{METODE PENELITIAN}

Metode yang digunakan dalam penyusunan artikel hasil penelitian ini adalah metode penelitian deskriptif kualitatif. Metode penelitian ini bertujuan menafsirkan dan menuturkan data yang bersangkutan dengan situasi yang sedang terjadi, sikap, dan pandangan yang terjadi di dalam masyarakat, pertentangan dua keadaan/lebih, hubungan antarvariabel, perbedaan antarfakta, pengaruh terhadap suatu kondisi, melalui studi kepustakaan baik dari buku, jurnal, ataupun referensi lain yang mendukung penelitian.

\section{DETERMINISME TEKNOLOGI KOMUNIKASI}

Segala tindakan dan kejadian
yang dilakukan manusia akibat perkembangan teknologi itu merupakan determinasi teknologi yang sebenarnya karena tanpa disadari manusia sudah terpengaruh segala sesuatu yang dibawa oleh teknologi. Perkembangan teknologi tersebut sering kali membuat manusia melakukan tindakan luar kendali. Pada awalnya teknologi diciptakan oleh manusia untuk memudahkan pekerjaan dan komunikasi. Akan tetapi, lambat laun justru teknologi memengaruhi setiap apa yang dilakukan manusia. Marshall McLuhan untuk pertama kali mengenalkan Teori Determinasi pada tahun 1962 dalam tulisannya yang berjudul "The Guttenberg Galaxy: The Making of Typographic Man”. Pokok gagasan dari teori ini adalah bahwa perubahan yang terjadi dalam berbagai macam cara berkomunikasi akan membentuk pula keberadaan manusia itu sendiri. Teknologi membentuk individu bagaimana cara berpikir, berperilaku dalam masyarakat dan teknologi tersebut akhirnya mengarahkan manusia untuk bergerak dari satu abad teknologi ke abad teknologi yang lain (McLuhan, 1994:108).

Media dalam bentuk apa pun merupakan alat untuk memperluas dan memperkuat pengaruhnya dalam pemikiran dan tindakan manusia. Dengan kata lain, masing-masing penemuan teknologi media baru yang betulbetul dipertimbangkan untuk memperluas beberapa kemampuan dan kecakapan manusia. Jika dikaitkan pemanfaatan teknologi bagi seni dan budaya dengan teori determinisme ini, manusia belajar merasa dan berpikir terhadap apa yang akan dilakukan karena pesan yang diterima teknologi menyediakan untuk itu.

Seperti halnya teknologi komunikasi yang menyediakan pesan dan membentuk perilaku manusia. Misalnya media radio menyediakan kepada manusia lewat indera pendengaran (audio), media fotografi menyediakan pesan kepada manusia melalui gambar (visual), sementara televisi menyediakan tidak hanya pendengaran, tetapi juga penglihatan (audiovisual). Apa yang diterpa dari ketiga media itu masuk ke dalam perasaan manusia dan memengaruhi kelangsungan hidup manusia. Semakin sering menggunakan teknologi, manusia semakin tidak dapat melepaskan ketergantungan terhadapnya.

\section{DETERMINISME GLOBALISASI MEDIA}

Melihat betapa besar peran media massa dalam memengaruhi pemikiran khalayaknya, tentulah perkembangan media massa di Indonesia pada masa akan datang tidak mungkin 
bisa terbendung lagi. Globalisasi media massa merupakan proses yang terjadi secara natural. Globalisasi membuat perbedaan yang ada antarnegara dalam dimensi ruang, waktu, dan kebudayaan semakin berkurang.

Proses globalisasi sudah terjadi sejak masuknya agama Hindu, Budha, atau Islam ke Nusantara. Proses ini bisa dimaknai sebagai salah satu bentuk globalisasi. Pada masa itu sekat-sekat yang membatasi wilayah dan kebudayaan nusantara terbuka dan pada akhirnya terjadi alkulturasi budaya dengan nilai-nilai yang ada dalam agama-agama tersebut. Akan tetapi, dalam konteks globalisasi di dunia komunikasi, globalisasi bertumbuh seiring sejalan dengan perkembangan teknologi informasi dan teknologi komunikasi. Dengan kata lain, pesatnya pertumbuhan alat komunikasi membuat globalisasi semakin pesat pula (Briggs dan Burke, 2006:210-212).

Globalisasi merupakan kecenderungan masyarakat untuk menyatu dengan dunia, terutama di bidang ilmu pengetahuan, teknologi, dan media komunikasi massa. Selain itu, para cendekiawan Barat mengatakan bahwa globalisasi merupakan suatu proses kehidupan yang serba luas, tidak terbatas, dan merangkum segala aspek kehidupan, seperti politik, sosial, dan ekonomi yang dapat dinikmati oleh seluruh umat manusia di dunia.

Mengingat bahwa dunia ditandai oleh kemajemukan (pluralitas) budaya, globalisasi sebagai proses juga ditandai sebagai suatu peristiwa yang terjadi di seluruh dunia secara lintas budaya yang sekaligus mewujudkan proses saling memengaruhi antarbudaya. Pertemuan antarbudaya itu tidak selalu berlangsung sebagai proses dua arah yang berimbang, tetapi dapat juga sebagai proses dominasi budaya yang satu terhadap yang lain.
Misalnya pengaruh budaya Barat lebih kuat terhadap budaya di negara Timur.

\section{PENGERTIAN BUDAYA}

Budaya atau kebudayaan berasal dari bahasa Sansekerta yaitu buddhayah, yang merupakan bentuk jamak dari buddhi (budi atau akal) diartikan sebagai hal-hal yang berkaitan dengan budi dan akal manusia. Dalam bahasa Inggris, kebudayaan disebut culture, yang berasal dari kata Latin Colere, yaitu mengolah atau mengerjakan. Bisa diartikan juga sebagai mengolah tanah atau bertani. Kata culture juga kadang diterjemahkan sebagai "kultur" dalam bahasa Indonesia (Damono, 1997:13).

Sebagai pengetahuan, kebudayaan merupakan suatu satuan ide yang ada dalam kepala manusia dan bukan merupakaan suatu gejala yang terdiri atas kebiasaan dan hasil kelakuan manusia. Kebudayaan terdiri atas serangkaian nilai, norma, dan larangan untuk melakukan suatu tindakan dalam menghadapi suatu lingkungan sosial dan kebudayaan.

\section{GLOBALISASI DAN BUDAYA}

Masyarakat Indonesia adalah masyarakat yang majemuk dalam berbagai hal, seperti keanekaragaman budaya, lingkungan alam, dan wilayah geografisnya. Keanekaragaman masyarakat Indonesia ini dapat dicerminkan juga dalam berbagai ekspresi kesenian. Dapat dikatakan pula bahwa berbagai kelompok masyarakat di Indonesia bisa dan mampu mengembangkan keseniannya yang sangat khas. Kesenian yang dikembangkannya itu menjadi model-model pengetahuan dalam masyarakat.

Salah satu aspek yang terpengaruh adalah kebudayaan. Terkait dengan kebudayaan, kebudayaan dapat diartikan sebagai nilai-nilai (values) yang dianut oleh masyarakat ataupun 
persepsi yang dimiliki oleh warga masyarakat terhadap berbagai banyak hal. Atau kebudayaan juga dapat didefinisikan sebagai wujudnya, yang mencakup gagasan atau ide, kelakuan dan hasil kelakuan (Koentjaraningrat, 2002:11), di mana hal-hal tersebut terwujud dalam kesenian tradisional Indonesia. Sebagai salah satu hasil pemikiran dan penemuan seseorang adalah kesenian, yang merupakan subsistem dari kebudayaan. Bagi bangsa Indonesia aspek kebudayaan merupakan salah satu kekuatan bangsa yang memiliki kekayaan nilai yang beragam, termasuk keseniannya. Kesenian rakyat, salah satu bagian dari kebudayaan bangsa Indonesia tidak luput dari pengaruh globalisasi.

Dengan adanya globalisasi dalam kebudayaan, tidak bisa dielakkan lagi perkembangan budaya semakin cepat. Globalisasi telah menimbulkan percepatan dan kemudahan dalam memperoleh akses berkomunikasi dan mendapatkan informasi apa pun. Tidak pelak semua ini justru menjadi bumerang tersendiri dan menjadi suatu masalah yang paling krusial dalam globalisasi.

Kenyataannya bahwa memang benar hingga saat ini perkembangan ilmu pengertahuan lebih didominasi oleh negaranegara maju dan bukan negara-negara berkembang seperti Indonesia. Negaranegara maju lebih memiliki dan mampu menggerakkan komunikasi internasional. Akibatnya, negara-negara berkembang, seperti Indonesia mengalami kekhawatiran besar dengan adanya arus globalisasi dalam berbagai bidang seperti ekonomi, sosial, politik, budaya, termasuk kesenian. Bukan hanya itu, kemajuan teknologi informasi pada masa sekarang ini telah dengan cepat mengubah kebudayaan Indonesia menjadi kian merosot. Dengan demikian, hal ini menimbulkan berbagai opini yang tidak jelas, yang nantinya akan melahirkan sebuah kebingungan di tengah-tengah berbagai perubahan yang berlangsung begitu rumit dan menimbulkan kebingungan-kebingungan bagi masyarakatnya sendiri.

Proses komunikasi dan transportasi internasional telah menghilangkan batas-batas budaya setiap bangsa. Kebudayaan setiap bangsa cenderung mengarah pada globalisasi dan menjadi peradaban dunia sehingga melibatkan manusia secara menyeluruh. Tindakan saling memengaruhi adalah gejala yang wajar dalam interaksi antarmasyarakat. Melalui interaksi dengan berbagai masyarakat lain, bangsa Indonesia ataupun kelompokkelompok masyarakat yang mendiami Indonesia telah mengalami proses dipengaruhi dan memengaruhi. Kemampuan untuk berubah merupakan sifat yang penting dalam kebudayaan manusia. Tanpa itu kebudayaan tidak mampu menyesuaikan diri dengan keadaan yang senantiasa berubah dan pada hakikatnya bangsa Indonesia dan bangsa-bangsa lain berkembang karena adanya pengaruh-pengaruh dari negara luar.

\section{PENYEBARAN BUDAYA DUNIA}

Globalisasi merupakan sebuah gejala tersebarnya nilai-nilai dan budaya tertentu ke seluruh dunia. Cikal bakal dari persebaran budaya dunia ini dapat ditelusuri dari perjalanan para penjelajah Eropa Barat ke berbagai tempat di dunia ini (Pye, 1966 dalam Barker 2004:174).

Dengan berkembangnya teknologi komunikasi, kontak budaya tidak lagi perlu melalui kontak fisik secara langsung. Hal ini karena kontak melalui media telah sangat memungkinkan. Karena kontak ini tidak bersifat fisik dan individual, ia bersifat massal yang melibatkan sejumlah besar orang (Klapper, 
1990 dalam Maryani 2011:93).

Dalam prosesnya banyak warga masyarakat yang terlibat dalam proses komunikasi global tersebut, dan dalam waktu yang bersamaan hal ini berarti banyak pula masyarakat yang menjadi exposed terhadap informasi, dan terkena dampak komunikasi tersebut. Sangat tidak mengherankan bila arus globalisasi berlangsung dengan cepat dan bersifat massal, sejalan dengan perkembangan teknologi komunikasi modern. Keunggulan media massa, baik cetak maupun elektronik, adalah bahwa media tersebut mampu menyuguhkan gambar-gambar secara jelas dan terinci kepada para pemakainya.

Sikap yang dapat muncul dari sini adalah sikap yang memandang secara kritis apa yang mereka miliki dan bagaimana mengimbanginya dengan nilai-nilai budaya lokal, termasuk sikap kritis dari bangsa Indonesia sendiri terhadap apa yang sudah dimiliki. Terkait dengan globalisasi, mitos yang hidup selama ini tentang globalisasi adalah bahwa proses globalisasi akan membuat dunia seragam. Proses globalisasi akan menghapus identitas dan jati diri. Kebudayaan lokal atau etnis akan ditelan oleh kekuatan budaya besar atau kekuatan budaya global.

Anggapan atau jalan pikiran tersebut tidak sepenuhnya benar. Kemajuan teknologi komunikasi memang telah membuat batas-batas dan jarak menjadi hilang dan tidak berguna.

Naisbitt (1988) dalam bukunya yang berjudul Global Paradox memperlihatkan hal yang bersifat paradoks dari fenomena globalisasi. Naisbitt(1988:173)mengemukakan pokok-pokok pikiran, yaitu semakin kita menjadi universal, maka tindakan kita semakin menjadi kesukuan atau lebih berorientasi 'kesukuan' dan berpikir secara lokal, namun bertindak global".
Hal yang dimaksudkan Naisbitt di sini adalah bahwa kita harus berkonsentrasi kepada hal-hal yang bersifat etnis, yang hanya dimiliki oleh kelompok atau masyarakat itu sendiri sebagai modal pengembangan ke dunia internasional. Dengan demikian, berpikir lokal, bertindak global, seperti yang dikemukakan Naisbitt tersebut, dapat diletakkan dan diposisikan pada masalah-masalah kesenian di Indonesia sebagai kekuatan yang penting pada era globalisasi ini.

\section{KONDISI KESENIANDAN KEBUDAYAAN PADA ERA GLOGALISASI}

Arus globalisasi membuat perubahan budaya terjadi di dalam masyarakat tradisional, yaitu perubahan dari masyarakat tertutup menjadi masyarakat yang lebih terbuka. Ilmu pengetahuan dan teknologi telah mengubah dunia secara mendasar. Komunikasi dan sarana transportasi internasional telah menghilangkan batas-batas budaya setiap bangsa.

Sekarang ini setiap hari kita bisa menyimak tayangan film di televisi yang bermuara dari negara-negara maju seperti Amerika Serikat, Jepang, dan Korea melalui stasiun televisi di tanah air. Belum lagi siaran televisi internasional yang bisa ditangkap melalui parabola yang kini makin banyak dimiliki masyarakat Indonesia. Sementara itu, kesenian-kesenian populer lain yang tersaji melalui kaset, $v c d$, dan $d v d$ yang berasal dari mancanegara pun makin marak kehadirannya. Hal ini tampak jelas sebagai bukti betapa negara-negara penguasa teknologi berhasil memegang kendali dalam globalisasi budaya khususnya di negara ketiga.

Kondisi ini sedikit banyak semakin membuat tersisihnya kesenian tradisional Indonesia dari kehidupan masyarakat Indonesia 
sendiri. Bentuk-bentuk ekspresi kesenian etnis Indonesia, baik yang rakyat maupun istana, selalu berkaitan erat dengan perilaku ritual masyarakat pertanian. Dengan datangnya perubahan sosial yang hadir sebagai akibat proses industrialisasi dan sistem ekonomi pasar, dan globalisasi informasi, kesenian Indonesia pun mulai bergeser ke arah kesenian yang berdimensi komersial. Kesenian-kesenian yang bersifat ritual mulai tersingkir dan kehilangan fungsinya. Sekalipun demikian, bukan berarti semua kesenian tradisional lenyap begitu saja. Ada berbagai kesenian yang masih menunjukkan eksistensi, bahkan secara kreatif terus berkembang tanpa harus tertindas proses modernisasi.

Di sisi lain, ada beberapa seni pertunjukan yang tetap eksis, tetapi telah mengalami perubahan fungsi. Ada pula kesenian yang mampu beradaptasi dan mentransformasikan diri dengan teknologi komunikasi yang telah menyatu dengan kehidupan masyarakat, misalnya kesenian tradisional "ketoprak" yang dipopulerkan ke layar kaca oleh kelompok Srimulat. Kenyataan tersebut menunjukkan bahwa kesenian ketoprak sesungguhnya memiliki penggemar tersendiri, terutama ketoprak yang disajikan dalam bentuk siaran televisi, bukan ketoprak panggung. Dari segi bentuk pementasan atau penyajian, ketoprak termasuk kesenian tradisional yang telah terbukti mampu beradaptasi dengan perubahan zaman.

Pada era globalisasi saat ini, eksistensi kesenian rakyat berada di titik yang rendah dan mengalami berbagai tantangan dan tekanan baik dari pengaruh luar maupun dari dalam. Tekanan dari pengaruh luar terhadap kesenian rakyat ini dapat dilihat dari pengaruh berbagai karya-karya kesenian populer dan juga karya-karya kesenian yang lebih modern, yang dikenal dengan budaya pop. Kesenian-kesenian populer tersebut lebih mempunyai keleluasan dan kemudahan dalam berbagai komunikasi baik secara alamiah maupun teknologi sehingga hal ini memberikan pengaruh terhadap masyarakat. Selain itu, aparat pemerintah nampaknya lebih mengutamakan atau memprioritaskan segi keuntungan ekonomi (bisnis) daripada segi budayanya sehingga kesenian rakyat semakin tertekan lagi.

Sesungguhnya, bagi kesenian rakyat Indonesia, kesempatan untuk mengadaptasi berbagai seni dari luar sangat cukup terbuka karena kekayaan kesenian yang dimiliki bangsa Indonesia sangat memadai untuk dikembangkan ke dunia internasional. Untuk menuju ke tindakan ini harus ada upaya atau perbaikan yang perlu diperhatikan agar kemasan kesenian tradisional bangsa Indonesia dapat diterima dan berkembang secara global, walaupun tetap mengacu pada kekuatan nilainilai asli dan kearifan lokal (local wisdom).

\section{KEBIJAKAN PEMERINTAH DALAM SENI DAN BUDAYA}

Peran kebijaksanaan pemerintah yang lebih mengarah pada pertimbanganpertimbangan ekonomi daripada budaya atau cultural, bisa dikatakan merugikan suatu perkembangan kebudayaan. Dalam buku yang berjudul Cultural Policy and The Performing Arts in South-East Asia diungkapkan bahwa kebijakan kultural di Asia Tenggara saat ini secara efektif mengubah dan merusak seniseni pertunjukan tradisional, baik melalui campur tangan, penanganan yang berlebihan, kebijakan-kebijakan tanpa arah, dan tidak ada perhatian yang diberikan pemerintah kepada kebijakan kultural atau konteks cultural (Lindsay, 1995:304).

Dari pengamatan yang lebih sempit terlihat tingkah laku aparat pemerintah dalam 
menangani perkembangan kesenian rakyat, yaitu banyaknya campur tangan dalam menentukan objek dan berusaha mengubah agar sesuai dengan tuntutan pembangunan. Kondisi seperti ini arti dari kesenian rakyat menjadi hambar dan tidak ada rasa seninya lagi. Dengan adanya kecenderungan tersebut, terlihat bahwa aparat pemerintah telah menjadikan para seniman dipandang sebagai objek pembangunan dan diminta untuk menyesuaikan diri dengan tuntutan simbol-simbol pembangunan.

Dengan demikian, kesenian rakyat semakin lama akan semakin kehilangan ruang yang cukup memadai untuk perkembangan secara alami atau natural. Secara tidak langsung kesenian rakyat akhirnya menjadi sangat tergantung oleh model-model pembangunan yang cenderung lebih modern dan rasional.

Dampak arus globalisasi media massa memang sangat besar terhadap seni dan budaya. Kontak budaya melalui media massa menyadarkan dan memberikan informasi tentang keberadaan nilai-nilai budaya dan kearifan lokal. Kontak budaya ini memberikan masukan yang penting bagi perubahan dan pengembangan nilai-nilai dan persepsi di kalangan masyarakat yang terlibat dalam proses ini.

Seni dan budaya bangsa Indonesia yang memiliki kekuatan etnis dari berbagai macam daerah juga tidak dapat lepas dari pengaruh kontak budaya ini. Dengan demikian, untuk melakukan penyesuaian-penyesuaian terhadap perubahan-perubahan diperlukan pengembangan yang bersifat global pula, namun tetap bercirikan kekuatan lokal, etnis, atau sesuai dengan kearifan lokal.

Globalisasi media dan budaya yang arusnya begitu pesat harus diantisipasi dengan memperkuat identitas seni dan budaya nasional. Berbagai kesenian tradisional adalah aset kekayaan kebudayaan nasional yang jangan sampai hanya menjadi alat atau slogan para pemegang kebijaksanaan, khususnya pemerintah, dalam rangka kepentingan pencitraan, politik, dan sebagainya. Pembinaan dan pengembangan kesenian tradisional yang dilakukan lembaga pemerintah selama ini masih hanya sebatas pada formalitas saja, tanpa menyentuh esensi kehidupan kesenian yang bersangkutan. Hal ini mengakibatkan seni dan budaya tradisional bukannya berkembang dan lestari, namun justru semakin dilupakan oleh masyarakat Indonesia sendiri.

Dengan demikian, tantangan yang dihadapi oleh kesenian rakyat cukup berat. Karena pada era teknologi dan komunikasi yang sangat canggih dan modern ini masyarakat dihadapkan pada banyaknya alternatif sebagai pilihan, baik dalam menentukan kualitas maupun selera. Hal ini sangat memungkinkan keberadaan dan eksistensi kesenian rakyat dapat dipandang dengan sebelah mata oleh masyarakat, jika dibandingkan dengan kesenian modern yang merupakan imbas dari budaya pop.

\section{DAMPAK GLOBALISASI TERHADAP BUDAYA BANGSA}

Globalisasi memengaruhi hampir semua aspek yang ada di masyarakat, termasuk di antaranya aspek budaya. Kebudayaan dapat diartikan sebagai nilai-nilai (values) yang dianut oleh masyarakat ataupun persepsi yang dimiliki oleh warga masyarakat terhadap berbagai hal. Baik nilai-nilai maupun persepsi yang berkaitan dengan aspek-aspek kejiwaan/psikologis, yaitu apa yang terdapat dalam alam pikiran. Aspekaspek kejiwaan ini menjadi penting artinya apabila disadari, bahwa tingkah laku seseorang sangat dipengaruhi oleh apa yang ada dalam alam pikiran orang yang bersangkutan. Sebagai 
salah satu hasil pemikiran dan penemuan seseorang adalah kesenian, yang merupakan subsistem dari kebudayaan.

Perkembangan transportasi, telekomunikasi, dan teknologi mengakibatkan berkurangnya keinginan untuk melestarikan budaya negeri sendiri. Derasnya arus informasi dan telekomunikasi ternyata menimbulkan sebuah kecenderungan yang mengarah terhadap memudarnya nilai-nilai pelestarian budaya. Saat ini, ketika teknologi semakin maju, ironisnya kebudayaan-kebudayaan daerah di Indonesia semakin lenyap di masyarakat, bahkan hanya dapat disaksikan di televisi.

Padahal seandainya kesenian dan kebudayaan daerah yang ada itu dikelola dengan baik selain menjadi potensi pariwisata seni dan budaya yang mampu menghasilkan dan meningkatkan pendapatan untuk pemerintah baik pusat maupun pemerintah daerah, juga dapat menjadi lahan pekerjaan yang menjanjikan bagi masyarakat sekitarnya. Perubahan tersebut menjadikan komunikasi antarbangsa lebih mudah dilakukan sehingga menyebabkan semakin cepatnya perkembangan globalisasi kebudayaan.

Ciri berkembangnya globalisasi kebudayaan di antaranya berkembangnya pertukaran kebudayaan internasional, penyebaran prinsip multikebudayaan (multiculturalism), dan kemudahan akses suatu individu terhadap kebudayaan lain di luar kebudayaannya, berkembangnya turisme dan pariwisata, semakin banyaknya imigrasi dari suatu negara ke negara lain, bertambah banyaknya event berskala global, persaingan bebas dalam bidang ekonomi, berkembangnya mode yang berskala global, seperti pakaian, film, dan musik.

Dampak positif akibat determinasi globalalisasi dalam segi sosial dan budaya di Indonesia di antaranya: (1) nilai sosial dan budaya Indonesia dapat diperkenalkan kepada dunia internasional. Bangsa Indonesia dapat memperkenalkan budaya dan objek pariwisata kepada negara lain agar menarik wisatawan asing untuk berkunjung ke Indonesia, ini tentu saja akan menambah devisa negara dan menguntungkan Indonesia dan (2) Indonesia dapat mengikuti kunjungan nilai sosial dan budaya dari negara lain sehingga bisa menyerap nilai budaya yang baik untuk dikembangkan di Indonesia tanpa mengubah jati diri bangsa Indonesia.

Dampak negatif determinasi globalisasi dalam segi sosial dan budaya di Indonesia di antaranya: (1) ada pertukaran budaya atau pengakuan budaya Indonesia oleh negara lain misalnya budaya Indonesia, yaitu Tari Pendet yang diakui oleh Negara Malaysia, ini tentu sangat merugikan bangsa Indonesia; (2) bangsa Indonesia lebih mengadopsi nilai-nilai yang dianut bangsa Barat sehingga mengakibatkan bangsa Indonesia kehilangan jati diri karena budaya Barat tidak sesuai dengan ideologi Negara Indonesia, yaitu Pancasila; (3) terjadi alkulturasi kebudayaan antara budaya Barat dan budaya Timur. Misalnya dalam gaya hidup, cara berpakaian, dan makanan. Ini tentu saja sangat merugikan karena kebanyakan budaya Barat tidak sesuai dengan norma-norma yang berlaku di Indonesia.

\section{TINDAKAN MENGANTISIPASI GLOBALISASI KESENIAN DAN KEBUDAYAAN}

Globalisasi merupakan media yang dapat difungsikan oleh bangsa Indonesia untuk mengelola budaya nasional menjadi go internasional. Dengan demikian, masyarakat 
dunia mengetahui bahwa Indonesia itu luas dan budayanya beraneka ragam. Indonesia tidak hanya Pulau Bali, tetapi juga ada Kalimantan, Sumatera, Sulawesi, Lombok, Papua, dan lainlain. Film Love, Eat and Pray yang sebagian ceritanya di Bali menjadi media promosi budaya nasional pada dunia internasional bagi Indonesia, walaupun Bali sudah menjadi trade mark pariwisata Indonesia.

Dengan berakhirnya era perang dingin, kekuatannasional suatubangsajuga terletakpada kekuatan ekonomi yang dapat dicapai dengan cara mengelola dan memanfaatkan sebaikbaiknya seni dan budaya nasional, walaupun tantangan budaya Barat atau westernisasi juga dirasakan begitu kuat pengaruhnya pada bangsa Indonesia. Dengan ditetapkannya batik sebagai bagian dari kebudayaan oleh UNESCO, pada dasarnya bangsa Indonesia mempunyai peluang yang sangat besar untuk terus mengembangkan budaya-budaya nasional yang lain dari berbagai daerah untuk menjadi bagian dari kebudayaan dunia.

Berbagai kesenian tradisional yang sesungguhnya menjadi aset kekayaan kebudayaan nasional jangan sampai hanya menjadi alat atau slogan para pemegang kebijaksanaan, khususnya pemerintah, dalam rangka keperluan turisme, politik, dan sebagainya. Selama ini pembinaan dan pengembangan kesenian tradisional yang dilakukan lembaga pemerintah masih sebatas pada unsur formalitas, tanpa menyentuh esensi kehidupan kesenian yang bersangkutan. Akibatnya, kesenian tradisional tersebut bukannya berkembang dan lestari, namun justru semakin dijauhi masyarakat. Dengan demikian, tantangan yang dihadapi oleh kesenian rakyat cukup berat. Karena pada era teknologi dan komunikasi yang sangat canggih dan modern ini masyarakat dihadapkan pada banyaknya alternatif sebagai pilihan, baik dalam menentukan kualitas maupun selera. Hal ini sangat memungkinkan keberadaan dan eksistensi kesenian rakyat dapat dipandang dengan sebelah mata oleh masyarakat, jika dibandingkan dengan kesenian modern yang merupakan imbas dari budaya pop.

Untuk menghadapi hal-hal tersebut ada beberapa alternatif untuk mengatasinya, yaitu meningkatkan Sumber Daya Manusia (SDM) bagi para seniman rakyat. Selain itu, mengembalikan peran aparat pemerintah sebagai pengayom dan pelindung, dan bukan sebaliknya justru menghancurkannya demi kekuasaan dan pembangunan yang berorientasi pada dana-dana proyek atau dana-dana untuk pembangunan dalam bidang ekonomi saja.

\section{SIMPULAN}

Pengaruh globalisasi di satu sisi ternyata menimbulkan pengaruh yang negatif bagi kebudayaan bangsa Indonesia. Normanorma yang terkandung dalam kebudayaan bangsa Indonesia perlahan-lahan mulai pudar. Gencarnya serbuan teknologi disertai nilai-nilai intrinsik yang diberlakukan di dalamnya telah menimbulkan isu mengenai globalisasi dan pada akhirnya menimbulkan nilai baru tentang kesatuan dunia. Dalam buku Eastern Religion and Western Though dinyatakan untuk kali pertama dalam sejarah umat manusia, kesadaran akan kesatuan dunia telah menghentakkan kita, entah suka atau tidak, Barat dan Timur telah menyatu dan tidak pernah lagi terpisah, Artinya adalah bahwa antara Barat dan Timur tidak ada lagi perbedaan (Radhakrishnan, 1924 dalam Abdulsyani, 2007:116).

Media massa merupakan sarana yang dapat dimanfaatkan untuk membantu 
masyarakat dalam menghadapi arus global. Media massa dapat memengaruhi pemikiran dan tingkah laku masyarakat menuju ke arah yang lebih baik ataupun lebih buruk. Maka dari itu, globalisasi tidak akan berkembang dengan pesat tanpa peranan media massa sehingga perlu dipertahankan aspek sosial budaya Indonesia sebagai identitas bangsa. Caranya adalah dengan penyaringan budaya yang masuk ke Indonesia dan pelestarian budaya bangsa.

Sebagaimana lontaran Gramsci yang terkenal dengan teori hegemoninya, untuk melepaskan diri dari cengkeraman budaya asing, diperlukan partisipasi keikutsertaan para intelektual organik kaum inteletual yang harus menyadarkan masyarakat, terutama generasi muda, bukan kaum inteletual tradisional yang justru lebih melegitimasikan budaya-budaya asing tersebut (Gramsci dalam Bocock, 2007:97).

\section{KEPUSTAKAAN}

Abdulsyani. 2007. Sosiologi: Skematika, Teori dan Terapan. Jakarta: Bumi Aksara.

Alo, Liliweri. 2011. Komunikasi Serba Ada Serba Makna. Jakarta: Kencana Media Prenada.

Barker, Chris. 2004, Cultural Studies Teori \& Praktik. Yogyakarta: Kreasi Wacana.

Briggs, Asa \& Peter Burke. 2006. A Social History of the Media. Terj. A. Rahman Zainuddin. Jakarta: Yayasan Obor Indonesia.

Bungin, Burhan. 2008, Konstruksi Sosial Media Massa; Kekuatan Pengaruh Media Massa, Iklan Televisi dan Keputusan konsumen serta Kritik Terhadap Peter Berger \& Thomas Luckmann. Jakarta: Kencana Prenada Media Group.

Damono, Sapardi Djoko. 1997. Kebudayaan Massa dalam Kebudayaan Indonesia: Sebuah Catatan Kecil dalam Ecstasy Gaya Hidup: Kebudayaan Pop dalam Masyarakat Komoditas Indonesia. Jakarta: Mizan.
Fakih, Mansour. 2006. Runtuhnya Teori Pembangunan dan Globalisasi. Cet. 4. Yogyakarta: Insist Press dan Pustaka Pelajar.

Ferguson, Marjorie. 2002. The Mythology About Globalization dalam Denis McQuail (Ed.) McQuail's Reader in Mass Communication Theory. London: Sage Publication.

Gramci Bocock, Robert. 2007. Hegemoni. Terj. Ikramullah Mahyuddin. Yogyakarta dan Bandung: Jalasutra.

Hamid, Farid dan Heri Budianto. 2011. Ilmu Komunikasi: Sekarang dan Tantangan Masa Depan. Jakarta: Kencana.

Hidayat, Dedy N. 1992. Globalisasi, Pascamodernisme dan Dunia Ketiga. Jakarta: Kompas.

Kuntowijoyo. 1997. Budaya Elite dan Budaya Massa dalam Ecstasy Gaya Hidup: Kebudayaan Pop dalam Masyarakat Komoditas Indonesia. Jakarta: Mizan.

Koenjaraningrat. 2002. Kebudayaan Mentalitas dan Pembangunan. Jakarta: Gramedia.

Lindsay, 1995. Cultural Policy and The Performing Arts in South-East Asia. Atlanta: U of Georgia.

Maryani, Eni. 2011. Media dan Perubahan Sosial: Suara Perlawanan Melalui Radio Komunitas. Bandung: Remaja Rosda Karya.

McLuhan, Marshall. 1994. Understanding Media: The Extension of Man. London: The MIT Press.

Morley, David. 2006. Globalisation and Cultural Imperialism Reconsidered: Old Question in New Guide dalam James Curran and David Morley (Ed.). Media and Cultural Theory. New York: Routledge.

Naisbitt, Yvonna S. 1988. Global Paradox. London: Sage Publication.

Nasution Zulkarimen. 2009. Komunikasi Pembangunan: Pengenalan Teori dan Penerapannya. Jakarta: Rajawali Press.

Nurudin. 2007. Pengantar Komunikasi Massa. Jakarta: Raja Grafindo Persada.

Sulastomo. 2003. Reformasi: Antara Harapan dan Realita. Jakarta: Penerbit Buku Kompas. 
Sigit Surahman, Determinisme Teknologi Komunikasi dan Globalisasi Media Terhadap Seni Budaya Indonesia

Swasono. 2003. Kemandirian Bangsa,

Tantangan Perjuangan dan

Entrepreneurship Indonesia.

Yogyakarta: Universitas Janabadra. 